\title{
O „FENOMENU“ ZADARSKOGA ŽENSKOG SLIKARSTVA U VRIJEME DRUGE AUSTRIJSKE UPRAVE
}

\author{
Mirisa Katić \\ Državni arhiv u Zadru \\ maria.mkatic@gmail.com
}

\section{SAŽETAK}

U radu se propituje pozicija ženske likovne aktivnosti u Zadru na prijelazu iz 19. u 20. stoljeće, koja nije zanemariva ni po broju autorica ni količini njihovih radova, što su se prikazivali na izložbama i komentirali u suvremenom tisku. Iako su dobivale nagrade i priznanja za svoje radove, zadarske umjetnice su marginalizirane do kraja 20. stoljeća, a njihovo ponovno otkrivanje vezano je za samo neka novija istraživanja suvremene zadarske historiografije. Slikarice, pripadnice plemićkih obitelji Borelli, Bogdanovich i Bottura, zauzimale su važno mjesto u likovnoj produkciji svoga vremena, unatoč teškoćama koje su morale svladavati jer nisu mogle raditi u istim uvjetima kao njihove muške kolege. Razlozi zanemarivanja mogu se pratiti od položaja u obitelji, izobrazbe i ovisnosti o bliskim muškarcima, do reakcija javnosti, likovne kritike i historiografije, koje i danas u mnogome utječu na poznavanje i ocjene njihove pozicioniranosti u korpusu hrvatske povijesti umjetnosti.

Ključne riječi: slikarice Zadru, slikarstvo za austrijske uprave u Dalmaciji, „fenomen“ ženskog slikarstva

\section{O SLIKARICAMA U LIKOVNOJ HISTORIOGRAFIJI}

Razlozi zbog kojih je mali broj likovnih umjetnika iz Dalmacije zastupljen u sintetskim radovima o hrvatskom slikarstvu 19. stoljeća vjerojatno su različiti, ali dalmatinski slikari nisu bili malobrojni niti su zaostajali u produkciji i kvaliteti, a nisu bili ni stranci što je moglo utjecati na zanimanje hrvatskih povjesničara umjetnosti. Stoga je teško objasniti činjenicu da se većim dijelom ne spominju. Moguće je da je tijekom 20. stoljeća u Zagrebu bilo otpora prema romanskoj kulturi i umjetnosti, možda i zavis- 
ti afirmiranih umjetnika školovanih u srednjoeuropskim centrima, kao i neprihvaćanja drugačijih pristupa i stilova (Travirka, 2011). Rezultat takvog odnosa je slabo poznavanje cjelokupne zadarske likovne produkcije toga razdoblja pa i ženske likovne djelatnosti, koja je, izgleda, baš u to doba dostigla prepoznatljive razmjere. Kada se krajem 20. stoljeća povećalo zanimanje za dalmatinske umjetnike iz vremena austrijske uprave istaknut je još jedan zadarski fenomen ${ }^{1}$, „žensko slikarstvo“ na prijelomu 19. i 20. stoljeća (Srhoj Čerina, 2008). Iako je novija zadarska historiografija zabilježila djelatnost pripadnica plemićkih obitelji Borelli, Bogdanovich i Bottura, ni one se ne spominju u hrvatskoj likovnoj historiografiji. Slikarica Antonietta Bogdanovich navodi se na nekoliko mjesta kao učenica slikara Josipa Rossija, a za ostale se zna samo iz natuknica knjižničara i filologa Pavla Galića u Hrvatskom biografskom leksikonu (HBL, 1989) i istraživanja Nedjeljke Balić-Nižić (2005). Podrobniji prikaz likovne djelatnosti slikarica, kćeri i nevjesta iz navedenih obitelji, koji je potom uslijedio spominje usput još poneku slikaricu kao npr. Angelicu Isolu, kći đenoveškog slikara i ženu Frane Salghetti-Driolija, koja je bila slikarica amaterka (Travirka, 2011). Osim šturih podataka o njihovu životu i opisa malo sačuvanih djela, povijest umjetnosti nije se mnogo bavila njima. Smatralo ih se osrednjim umjetnicama, a njihova djela amaterskim radovima pa su nakon nekog vremena prepuštene zaboravu.

Radovi povjesničara umjetnosti Marije Stagličić i Antuna Travirke predstavljaju prekretnicu u istraživanju djelatnosti zadarskih umjetnica jer je globalno zanemarivanje ženskog stvaralaštva i tu vidljivo. Činjenica da su žene uvijek morale svladavati više prepreka i uložiti više truda da bi postigle isto što i njihove kolege, pojačana je u ovom slučaju, provincijskim položajem Dalmacije u odnosu na državna središta. Stoga ne iznenađuje to što se u zadarskom ženskom slikarstvu javljaju samo plemkinje koje su, barem na početku, mogle računati na moralnu i financijsku podršku svoje (očeve) obitelji jer je zadarsko plemstvo zadržalo tradiciju njegovanja kulture i umjetnosti, a svojim potomcima je nastojalo osigurati i odgovarajuće obrazovanje. Cilj ovog rada, je na temelju šturih i razbacanih historiografskih podataka i izvora, pokušati objasniti ulogu ženskoga umjetničkog rada u razdoblju koje im nije bilo nimalo sklono te njihovu poziciju u umjetničkom životu grada i uzroke kasnijega posvemašnjeg zaborava. U 19. stoljeću žene nisu imale nikakvih prava, zakon ih je tretirao isto kao i djecu o kojoj je netko morao brinuti, a njihov razvoj od djetinjstva do zrelosti pratile su prepreke od edukativnih ograničenja, intelektualnog i moralnog podcjenjivanja, materijalnih teškoća i obiteljskih odluka koje nisu uvažavale i njihove želje.

Simone de Beauvoir je tvrdila da se ženom ne rađa, nego da se ženom postaje (De Beauvoir, 2006), Jacques Lacan zastupao je tezu da žena ne postoji, već da je ženskost, psihoanalitički govoreći, konstruirana od niza predodžbi (Linkler, 1999), a feministička kritika povijesti umjetnosti polazi od dekonstrukcije mita o njezinoj političkoj, ekonomskoj i rodnoj neutralnosti. Ona postupno razotkriva „skrivene sadržaje, naknadno konstruirana značenja i sumnjive pretpostavke, koje leže u metodološkim osnovama povijesti umjetnosti.“ (Kolešnik, 1999, VI). Novija povijest umjetnosti je naglašavala potrebu istraživanja socijalnog konteksta i nužnost ispitivanja uvjeta njegove recepcije, zagovara-

1 Pored poznatih „fenomena“ stare zadarske fotografije i umjetničke fotografije braće Brkan. 
jući stvaranje interpretativno-teorijskog okvira vezanog za šire kulturno, političko i ideološko područje. Feministička kritika je pokazala da je „diskurs tradicionalne povijesti umjetnosti samo prividno socijalno i politički beznačajan, udaljen i izoliran od socijalnih konflikata i uvjeta socijalnog života“ $i$ da "povijest umjetnosti nije samo pasivno bilježenje egzistencije prethodno stvorenih predmeta, već i način izravnog utjecaja na tekuću likovnu produkciju, koja, zauzvrat, proizvodi socijalne predodžbe i konstituente specifičnih vrsta znanja ili svijesti o određenim tipovima društvenih odnosa" (Kolešnik, 1999, VII). Feministička kritika zaključuje da su rodne razlike ugrađene u temelje visoke kulture i da podrazumijevaju isključivanje žena iz povijesti umjetnosti, jer mitovi o prirodi umjetnika slave muški kreativni subjekt. Ona je potvrdila da su umjetnice postojale u prošlosti, da su ponekad bile vrlo uspješne i poznate, ali njihov utjecaj nije bio snažan kao utjecaj i moć nekih njihovih suvremenika. Razlog tome feminističke povjesničarke umjetnosti vide $\mathrm{u}$ kulturnim i ideološkim ograničenjima vezanim za socijalnu konstrukciju roda koja je određivala stupanj dostupnosti izobrazbe, izlagačku politiku i način recepcije muške i ženske likovne produkcije. Uz to, istaknule su ulogu povjesničara umjetnosti, najčešće muškaraca, i njihovu rodnu pristranost, kao i potrebu promjene načina razmišljanja uz odbacivanje stajališta prema kojemu kreativnost pripada isključivo autonomnom području umjetnosti. Neke autorice su, polazeći od Markusova modela totaliteta socijalnih snaga, smatrale da umjetničko djelo treba promatrati u kontekstu cjeline društva, jer je i ono društveno uvjetovano, a predodžbe koje donosi obilježene su različitim konvencijama označavanja, tako da je ono, kao sredstvo koje pokreće socijalne procese, uvjetovano načinom prikazivanja i temom tipičnom za pripadajuće razdoblje. Feministička teorija ukazala je na oblike ponašanja i odnose moći koji su, iako na prvi pogled društveno prihvatljivi i „prirodni," u biti ideološki i kultorološki determinirani patrijarhalnim ustrojem društva, a Griselda Pollock skrenula pažnju na preglede umjetnosti 20. stoljeća koje obilježava usredotočenost na muške "genije, očeve, začetnike i rodonačelnike.“ (Kolešnik, 1999, VIII).

\section{KAKO SU STVARALE UMJETNICE}

Na pitanje, zašto nema velikih umjetnica, Linda Nochlin je pokušala odgovoriti na nekoliko načina. Prvi je bio pokušaj traženja primjera vrijednih, a nedovoljno cijenjenih umjetnica u povijesti, njihovo rehabilitiranje i ponovno otkrivanje. Drugi odgovor uključio je istraživanje mogućnosti postojanja drugačijega ženskog stila posebnih formalnih i izražajnih značajki utemeljenih na specifičnosti ženskog iskustva, ali nije uspjela pronaći primjere takve ženske grupe ili pokreta jer nikakve zajedničke ili „ženstvene“ značajke ne povezuju individualne stilove umjetnica. Naprotiv, umjetnice su bliže drugim umjetnicima svoga vremena (bez obzira na spol), nego jedna drugoj. To je, tvrdi Nochlin, stoga što stvaranje umjetnosti nije osobni izraz individualnoga emocionalnog iskustva, prijevod osobnog života u termine likovnosti, nego pretpostavlja dosljednu primjenu određenog formalnog jezika koji ovisi o konvencijama, shemama i sustavima što ih je potrebno naučiti, usavršiti izobrazbom i dugotrajnim individualnim eksperimentiran- 
jem. Zaključila je da vjerojatno nije bilo velikih likovnih umjetnica u povijesti, ali je bilo mnogo zanimljivih i vrlo dobrih čiji rad nije dovoljno istražen, prikazan i odgovarajuće valoriziran (Nochlin, 1999).

Ako se vratimo na fenomen ponovno otkrivenih zadarskih likovnih umjetnica, vidjet ćemo da se njihova sudbina većim dijelom podudara s onim što se događalo i u drugim područjima zapadne kulture. Umjetnički nadarene djevojčice usmjeravalo se, kao i sve ostale, na vještine potrebne za kućanske poslove, odgoj ćudoređa, krotkosti i poslušnosti. U Zadru su tijekom 19. stoljeća mogle dobiti najviše dvije godine pučke izobrazbe (čitanje, pisanje, računanje i ženske ručne radnje), a nakon toga najviše još tri godine u nekom zavodu za odgoj djevojaka (izvan Zadra), gdje je izobrazba uključivala još kaligrafiju, crtanje i glazbu. Iako su poezija, slikarstvo i glazba bili integralni dio odgoja i svakodnevnog života građanskih i plemićkih djevojaka, one su se u tim zavodima pripremale u prvom redu za poslove supruge/kućanice u nekome građanskom domu, što su ga odabirali roditelji.

Većina zadarskih slikarica pohađala je zavode i akademije u Austriji ili Italiji, ali ženske škole nisu imale iste programe kao muške, već su oni bili puno konzervativniji i površniji, prilagođeni njihovim pretpostavljenim „slabijim“ mogućnostima. Kada im je i bilo dopušteno pohađati ista predavanja, nisu smjele pristupiti crtanju prema modelu. Nagi modeli, muški i ženski, uvijek su bili dostupni samo muškarcima, a slikarice su se morale ograničiti na portrete, krajolike i mrtve prirode (Nochlin, 1999). Akademska izobrazba, sustav naukovanja i umjetnička praksa podrazumijevali su način života podređen umjetnosti, što je ženama bilo moguće samo ako su imale podršku obitelji, tj. oca umjetnika ili su bile u vezi s jačim i dominantnim mužem, koji su ih poticali i ohrabrivali. Sve do kraja 19. stoljeća likovna djelatnost žena smatrala se amaterizmom, iako je među njima bilo onih koje su završile studije i ostvarile zapažene umjetničke rezultate. $S$ druge strane, ženski amaterizam je bio poželjan način ispunjavanja slobodnog vremena i terapija imućnih žena, ali samo nakon što bi zadovoljile sve druge „ženske“ obaveze. Dok se muška ambicioznost smatrala vrlinom, ženska se uporno obuzdavala, a školovane slikarice su rijetko dobivale službene narudžbe i priznanja. Pohvale koje su dolazile od novinara, komentatora pa i kritičara u povodu održavanja izložbi i nastupa bile su često kurtoazne prirode i nisu ostavljale dubljeg traga u kolektivnoj memoriji. Obezvređivanje ženskih radova i edukativna praksa koja ulazi u konstrukt ženskosti je opće mjesto i u povijesti umjetnosti.

Kada se govori o ženskom stvaralaštvu, u njemu je uvijek važnu ulogu igrala podrška naklonjenog muškarca, ali i bračni status, koji je s jedne strane mogao donijeti poticaj i materijalnu sigurnost, a s druge odustajanje „zbog obiteljskih obaveza.“ Tako su, osim amaterki, i školovane žene često zapuštale svoju djelatnost. Ne znamo kakvi su bili izobrazba i radovi jedne od prvih slikarica, koje se u 19. stoljeću spominju u Zadru, Đenovljanke Angelice Salghetti-Drioli, rođ. Isola, koju povjesničar umjetnosti Alfred Petričić samo usputno spominje u tekstu o njezinom mužu Frani, kao "kćer slikara Andrea, koju kasnije uzima za ženu” (Petričić, 1959, 220), ali ona je tijekom 13 godina braka rodila čak osmero djece i umrla mlada u porodu, 1853. godine. Teško je zamisliti da se u tim uvjetima mogla posvetiti umjetnosti, mada njihova obitelj nije živjela od muževljeva 
slikarstva, nego od proizvodnje likera. Ovdje možemo spomenuti i njezinu svekrvu Giuseppinu Salghetti-Drioli, rođ. Bassan, koja je nakon smrti muža morala preuzeti vođenje tvornice. Sinove je poslala u Italiju na školovanje, što je potrajalo dvadesetak godina. Frane je u Italiji „potrošio" punih 18 godina i vratio se tek nakon ženidbe. Silom prilika Giuseppina je postala tvorničarka i danas se navodi kao jedna od rijetkih uspješnih poslovnih žena svoga doba. ${ }^{2}$

Koliko je mladićima bilo lakše nego djevojkama koje su odabrale umjetnički poziv vidi se i iz primjera svestrane Itale Bogdanovich (1874.-1945.), koja se nakon tri godine provedene na studiju u Rimu, morala zbog loše obiteljske financijske situacije, vratiti u Zadar. Pitanje je bi li otac tolerirao dugogodišnje kćerino studiranje u inozemstvu i da su imali sredstava, kao što je „morala“ Giuseppina, koja je k tome bila i „stroga majka, "ili bi ipak, kao Držićev dundo Maroje, otišao provjeriti što mu dijete radi u Rimu. Za sestre Bogdanovich se smatra da su naslijedile talent od oca, koji je bio dobar crtač i krasopisac pa je moguće da su od njega primile prve poduke. Kasnije su dvije od njih studirale slikarstvo i neko vrijeme profesionalno djelovale, dok su druge dvije bile amaterke ostavivši za sobom tek nekoliko sačuvanih radova. Nakon udaje Tereza i Amelija su povremeno slikale i izlagale u Zadru, a kritika je hvalila njihove portrete rodbine, prijatelja i autoportrete. Tereza je umrla mlada "od posljedica poroda," a o Ameliji se još premalo zna.

Najstarija, Antonietta Bogdanovich, udana Cetineo (1857.-1941.), imala je uspješnu umjetničku karijeru i bila poznata na nekim europskim dvorovima gdje je portretirala članove vladarskih obitelji. Studirala je slikarstvo, radila u Beču i Trstu, a u Zadru je prvi put izlagala kada je imala samo 23 godine. Ona je bila jedna od rijetkih slikarica toga razdoblja koja je i zarađivala slikajući: naslikala je portret cara Franje Josipa I. i nekih političara. Dok je Antonietta osvajala europske dvorove, udala se i udaljila od obitelji, najmlađa Itala Bogdanovich se, ne dovršivši studij vratila u Zadar pred kraj stoljeća. I ona je pokušala živjeti od slikanja, izrađivala portrete i slike za crkve, održavala satove crtanja, no to je bila i suviše smiona odluka za ženu u gradu u kojemu ni građanski industrijski ni poduzetnički sloj nije pokazivao previše sklonosti prema slikarstvu, prihvaćajući ga više kao oblik i modu, nego kao živi izraz moderne estetike. U drugoj polovini 19. stoljeća u Zadru se snažno razvija fotografska djelatnost, a tiskarstvo i izdavaštvo se nije otvaralo novim idejama, nego je više služilo dnevno-političkim potrebama. Portrete su naručivali samo neki crkveni krugovi, plemićke i građanske obitelji, političari i vladini dužnosnici, što nije bilo dovoljno da bi potaklo veću likovnu produkciju. Iako se, nakon rušenja gradskih bedema i izgradnje brojnih novih državnih i privatnih zgrada, moglo očekivati više interesa za njihovo uređenje, ukrašavanje i oslikavanje, to se nije dogodilo u većoj mjeri. Itala je portretirala rodbinu i prijatelje, a od 1904. godine nekoliko puta je izlagala u Zadru i jednom u Veneciji. Nakon toga dobila je dozvolu za otvaranje slikarske i crtačke škole u Zadru, ali poznato je samo da je održala tečaj crtanja 1917. godine u Obrtnoj školi. Nakon rata nije više imala posla pa je čak bila prisiljena zatražiti državnu novčanu pomoć 1924. godine. U teškoj financijskoj i životnoj situaciji Itala se okrenula pisanju jer

2 Uspješno je vodila tvornicu likera od 1822. do 1843. godine, pa se o njoj danas govori kao o poduzetnici koja je djelovala u vrijeme kada je bilo malo žena u tim poslovima. 
je ono jednostavnije i svakako iziskuje manje troškova nego slikanje. Sva njezina književna djela (na talijanskom jeziku), poezija, drame, životopis i leksikon Donne illustri ostala su u rukopisima (Balić-Nižić, 2005), koji se čuvaju u Znanstvenoj knjižnici u Zadru, a u Narodnom muzeju u Zadru je jedan autoportret iz 1923. godine. Za Antoniettu je Itala u svom Dnevniku napisala da se pred kraj života vratila u Zadar sama, siromašna i zaboravljena moleći sestru, s kojom nije komunicirala dugi niz godina, da je primi u svoj stan, gdje ih je pomeo Drugi svjetski rat.

Slikarice iz kneževske obitelji Borelli imale su više prilike za razvijanje talenata i umjetničkih sklonosti. Uz podršku obitelji školovale su se i izlagale od Beča do Zagreba, Rima, Pariza i Splita. Najstarija kći Frane Borellija, Angelina, udana Maschek (1838.1925.), slikala je samo u mladosti, do udaje i sačuvani su neki njezini crteži i akvareli. Od mlađe, Zoe Borelli (1853.-1887.), ostalo je nekoliko slika, a od nevjeste, Antonette de Marassovich-Borelli (1867.-1931.), rodom iz Skradina, sačuvan je samo jedan crtež iz kojega se vidi stanovita vještina baratanja medijem. Posebno je zanimljiva svestrana Silvia Borelli, udana (drugi brak) Benja (1863.-1956.), koja je nastupala veoma samouvjereno baveći se „svim slobodnim umjetnostima“ (Travirka, 2011, 561). U spisima jedne od najstarijih zadarskih obitelji, Benja (Begna) Benković, u Državnom arhivu u Zadru, nalazi se 17 originalnih portreta i ilustracija u bojama s potpisom: Begna 1906. i 1907., koji još nisu precizno atribuirani, ali izvori i usmena predaja govore da ih je izradila Silvia, što bi trebalo podrobnije istražiti.

Najpoznatija i najuspješnija, Zoe Borelli Vranski-Alačević (1888.-1980), koja je veći dio života provela u Italiji, prvu poduku i podršku dobila je od talentiranog oca Huga Borellija, a slikarstvo je studirala u Zagrebu, Beču i Rimu. Za vrijeme studija i do udaje družila se s drugim hrvatskim slikarima i slikaricama, među ostalima s Nastom Rojc, koja ju je portretirala 1909. godine. U Zadru je boravila s prekidima do kraja Prvoga svjetskog rata istražujući narodne rukotvorine, nošnje i običaje. Okušala se u raznim tehnikama, ali je, kao i većina drugih slikarica, najčešće slikala pejzaže, portrete, crteže pa i karikature. Podršku i poticaje oca imale su i dvije kćeri profesora Petra Botture, Margherita (Rita) i Gina, koje su pohađale privatne slikarske tečajeve. Starija, Rita, udala se za kipara Bruna Bersu, koji je podržavao njezin rad pa je nastavila slikati, a od djela njezine sestre Gine sačuvan je samo jedan portret. Iako su izlagale na izložbama u Zadru i Splitu malo se zna o njihovu životu, izložbama, katalozima i kontaktima; bile su zaboravljene čitavo jedno stoljeće i sada se ponovno otkrivaju kao i njihovi radovi.

\section{KAKO POČINJE ZABORAV}

Zanemarivanje, podcjenjivanje i zaborav ženske likovne produkcije, mogu se pratiti sve do naših dana, a povezani su i s najboljom slikom, La fumatrice, Antoniette Bogdanovich Cetineo, koja se čuva u Modernoj galeriji u Zagrebu. Krajem 2012. godine u Zagrebu je organizirana velika izložba pod naslovom Kultura pušenja - od tabua do tabua, na kojoj je interdisciplinarno tematizirana ova „povijest industrije grijeha. U realizaciji izložbe i opširnoga, dobro opremljenog kataloga, sudjelovali brojni autori, koji su 
s različitih stajališta obradili povijest, kulturu i simboliku pušenja kao muške aktivnosti vezane za materijalni, društveni, kulturni pa i rodni status. Pišući o strasti cara Franje prema pušenju i posebnim cigaretama, što mu ih je donosila prijateljica „s kojom se tješio za vrijeme razuzdanih europskih provoda vesele i energične carice Elizabete Bavarske, poznate kao Sisi,“ autor se okomio na caricu koja je „promovirala slobodu pušenja za žene u Monarhiji“ (Skoko, 2012, 34) obrazlažući njezine postupke time što je teško podnosila konzervativizam bečkog dvora, svekrve i muža pa je provokativno pušila u javnosti, što je izazivalo sablazan jer se pušenje smatralo nepristojnim činom, kojega su i muškarci „skrivali“ od svojih žena. Muška pušačka strast povezuje se s drugim oblicima raskalašenog života, društvenom aktivnošću i zabavama, kockanjem, javnim kućama, kabareima i predstavama u kojima su žene nastupale u službi muške zabave i za novac. Pri tome se ponašanje muškaraca opravdava potrebom za odmorom od obaveza i posla, a žene i pušenje postavljaju se u negativni kontekst koji ne pruža opravdanje. Na kraju članka o duhanskoj industriji umetnuta je velika fotografija mnoštva tvorničkih radnica s rupcem na glavi, koje sjede ispred tvornice kao u koncentracijskom logoru. Motiv žena što za sitan novac služe industriji muške zabave ponovno ih stavlja u kontekst neizbježne kolateralne žrtve. Slika Antoniette Bogdanovich-Cetineo, na kojoj je 1900. godine u Trstu naslikala mlađu sestru Italu s cigaretom, svakako je trebala biti uključena u ovu izložbu prema motivu, ali i kvalitetom, koju su potvrdili i povjesničari umjetnosti koji su o njoj pisali (Stagličić, 2011), (Travirka, 2011).

U biografiji Itale Bogdanovich važan je događaj koji je, po svemu sudeći, snažno utjecao na njezin daljnji život i karijeru, kao i dugogodišnji prekid komunikacije sa sestrom Antoniettom. Bio je to neočekivani emocionalni istup prema jednoj učenici, kojega je u trenutku naivne iskrenosti priznala. Nije mogla pretpostaviti da će okolina tako brzo i oštro obračunati sa svakom naznakom iskoraka koji bi mogao dovesti u pitanje paradigmu društvenoga i „prirodnog“ spolnog poretka. Kažnjena je društvenim prezirom i izolacijom kojima se sama nije mogla oduprijeti, iako nije dala povoda sumnjama u homoseksualne sklonosti, nego je prisnu vezu objasnila kao bliskost koja ju je podsjećala na pokojnu sestru blizanku. Ovaj događaj, povezan sa slikarskom djelatnošću, koincidira sa sličnim iskustvima umjetnika i umjetnica s početka 20. stoljeća, kada su takve veze bile u modi pa je i zadarska javnost vjerojatno znala za to. Francuska slikarica Rosa Bonheur (1822.-1899.) izjavila je da se nije htjela udati jer se bojala gubljenja neovisnosti (Nochlin, 1999), nego je živjela s prijateljicom. Drugačije je postupila hrvatska slikarica Nasta Rojc (1883.-1964.), koja je samouvjerena, uspješna, bogata i samostalna u mladosti otvoreno prkosila društvenim konvencijama i održavala homoseksualnu vezu (Kolešnik, 2000).

\section{O VREDNOVANJU I POZICIONIRANJU ŽENSKE UMJETNOSTI}

Pitanje vrednovanja iz uvodnog dijela može se proširiti još jednim, koje se češće odnosi na novija, nego na starija umjetnička djela: što je umjetnost? S obzirom da se predodžba publike o umjetnosti oslanja na sustav zadanih očekivanja, koja se ponašaju kao zakoni, sudovi publike utemeljeni su na otporu onome što ruši statičnu sliku njezina 
ukusa. U trenutku kada se ukus mase nametne kao zakon umjetnosti, kritičkom kompetentnom sudu je potrebna dodatna interpretativna strategija posredovanja, a važnu ulogu u tome ima umjetnička kritika kao medijator između povijesti i suvremenosti (Lah, 2012, 273). Odlučujuću ulogu ima stav povjesničara umjetnosti, koji iz vremenske distance vrednuju ne samo djela i osobe, nego i pokrete i stilska razdoblja. Dobar primjer za to je vrednovanje djela već spomenutoga zadarskog slikara Frane Salghetti-Driolija (1811.1877.), koji se danas smatra jednim od najvećih hrvatskih slikara 19. stoljeća. Sredinom 20. stoljeća drugačije se gledalo na slikarstvo toga razdoblja, a pedesetak godina kasnije, nakon što je ono oslobođeno od teorijskih ograničenja i predrasuda, akademik Ivo Petricioli je priznao: „Takav rezervirani stav prema slikarstvu XIX. stoljeća općenito, a prema Salghettiju posebno, imao sam i ja izražavajući se kritično o njegovim djelima. Baveći se efemerno Salghettijem učinio sam to više puta pa se osjećam dužnim, nakon što smo njegov rad bolje upoznali i postavili u kontekst umjetničkih zbivanja toga vremena u nas i u Italiji, ispričati se slikaru i opravdati svoj stav ... Spomenuo sam, ne jednom, da je Salghetti bio ograničena talenta. To je zaista prestrog sud, a proizlazi iz tadašnjeg mog stava prema akademizmu uopće" (Petricioli, 2003, 12).

Kada je u pitanju žensko slikarstvo Ljiljana Kolešnik razmišlja kako „veliki broj umjetnica ranog modernizma ... zasniva svoj stil na „zastarjelim oblicima umjetničke prakse, čiju estetiku većina njihovih muških kolega odbacuje iz strateških razloga već početkom stoljeća“ i pita se: „Je li doista riječ samo o nedovoljnoj i neodgovarajućoj naobrazbi, o rodno uvjetovanoj nezainteresiranosti za suvremene likovne poetike, ili je u pitanju nešto drugo? Možda su na kritičku recepciju ženskih opusa, osim krute primjene kriterija formalne inovacije, utjecali i određeni elementi koji u većoj mjeri pripadaju krugu općih kulturoloških problema te se stoga nalaze izvan područja neposrednog interesa modernističke likovne kritike? Na primjer, određeni rodni stereotipi za koje feministička likovna kritika tvrdi kako su ugrađeni u sam temelj konstrukcije ženske uloge u kulturi ranog modernizma. Američka autorica Celeste Schenck će posebno istaknuti dva stereotipa. Prema njima žene su uvijek „istovremeno 'ispod' kulture - previše uronjene u prirodu da bi svladale kodove poetskih i likovnih formi ... ili čuvarice' kulture - stroge rigidne, konzervativne, vezane uz socijalne norme, sklone potiskivanju spontanosti i eksperimenta." (Kolešnik, 2000, 188-189). Autorica ističe da brojna pitanja i dileme koji se nameću, zahtijevaju najprije temeljitu i nepristranu historiografsku obradu, kao i novi kritičko-povijesni pogled te da je potrebno oblikovati poseban teorijski okvir, koji će omogućiti uočavanje osobitosti ženskih radova. Ipak, da bi se izbjeglo zamke feminističkog stereotipa, koji izdvaja ženske radove prema samoj rodnoj pripadnosti, potrebno je naglasiti njihovu raznolikost, posebnosti pojedinih autorica i njihovih djela i prepoznati zajednička ženska obilježja koja su rezultat odgoja i utjecaja povijesno promjenjivih društvenih sustava što generiraju spolne razlike, a ne same prirode (Pollock, 1999). Prema feminističkoj likovnoj kritici, samo povijest umjetnosti koja se bavi i ženskom likovnom produkcijom, kao i mjestom žene u sustavu označavanja muške moći i privilegija, može ostati „vjerna i povijesti ženskog prinosa vizualnim umjetnostima i aktualnoj političkoj, odnosno intelektualnoj kritici koja mora nastaviti obilježavati feminističku znanost." (Chadwick, 1999, 213). 


\section{ZAKLJUČAK}

Sudjelovanje žena u kulturnom, umjetničkom, prosvjetnom pa i društvenom životu Dalmacije nije nepoznanica jer se u historiografiji spominju u raznim aktivnostima. U likovnoj umjetnosti u Zadru prva ženska imena zabilježena su u drugoj polovini 19. stoljeća, ali njihovi radovi, ma kako ozbiljno bili prihvaćeni i uključeni u suvremene tokove i manifestacije, nisu ostavili traga u povijesti likovne umjetnosti. Tek najnovija historiografska istraživanja, povezana s oživljavanjem zapostavljene cjelokupne umjetničke memorije Dalmacije iz vremena austrijske uprave, iznijela su na vidjelo i djelovanje zadarskih slikarica. Pokazalo se da su se pripadnice nekih plemićkih obitelji ozbiljno bavile slikarstvom i da su neke od njih ostvarile zapažene rezultate nastupajući na izložbama u više europskih gradova.

Od četrnaest slikarica pet ih je steklo odgovarajuću akademsku izobrazbu, a dvije su se neko vrijeme profesionalno bavile tim poslom. Obitelj Bogdanovich dala je četiri slikarice od kojih su dvije studirale u Beču i Rimu. Najstarija, Antonietta, djelovala je u Beču i Trstu, a najmlađa, Itala, u Rimu i Zadru, no obje su doživjele tešku sudbinu i siromaštvo u rodnom gradu u kojemu nije bilo dovoljno zanimanja za radove umjetnika uopće. U obitelji Borelli bilo je sedam žena uključenih u likovne djelatnosti, od slikarstva i kiparstva do primijenjenih umjetnosti, od kojih su tri završile likovnu akademiju. Zoe Boreli Vranski-Alačević ostvarila je najbogatiji opus koji još nije ni dovoljno istražen. Sve su slikale i izlagale samo u mladosti, do udaje i dok su imale podršku oca ili muža, a one koje su se pokušavale i kasnije baviti tim poslom nisu uspijevale ili je njihov opus danas nepoznat. Neke od njih su umrle mlade, nakon brojnih i učestalih poroda, a neke su morale zapostaviti slikanje i posvetiti se obiteljskim obvezama. Nije neobično što su u Zadru samo plemkinje pokazale interes za likovno izražavanje jer su one mogle pohađati skupe djevojačke škole i akademije u inozemstvu, dok su građanske djevojke češće završavale učiteljske škole, koje su im, pored opće izobrazbe i kućanskih praktičnih vještina, omogućavale zaposlenje u nekoj djevojačkoj školi. Najveći problemi u poznavanju života i rada zadarskih slikarica su zaborav, ignoriranje i podcjenjivanje koji su prekrili njihove biografije. Mnogi radovi su im uništeni, izgubljeni ili zagubljeni, rijetki su potomci koji su ih pamtili ili sačuvali, a još je manje onih koji su nešto napisali o njima. Nakon prvih podataka što ih je Pavao Galić iznio u Hrvatskome biografskom leksikonu uključili su se i neki drugi istraživači i historiografi pa se možemo nadati da će tzv. "fenomen" zadarskoga ženskog slikarstva biti proučen i postavljen na mjesto koje mu pripada u hrvatskoj kulturnoj i umjetničkoj povijesti.

\section{LITERATURA}

1. Balić-Nižić, N. (2005). Hrvatice u biografskom rječniku "Donne illustri” Itale Bogdanović (1874.-1945.). Croatica et slavica Iadertina, I (1): 251-266.

2. Begna, A. (1907). Stammbaum der Familie Begna-Benkovič, DAZD, Zbirka rukopisa, 98 . 
3. Chadwick, W. (1999). Umjetnice i politika prikazivanja. U: Lj. Kolešnik (ur.), Feministička likovna kritika i teorija likovnih umjetnosti: izabrani tekstovi, Zagreb, 1999 (197-214). Zagreb: Centar za ženske studije.

4. De Beauvoir, S. (2006). Drugi spol. U: N. Čačinovič (ur.), Žene i filozofija, Zagreb, 2006 (135-162). Zagreb: Centar za ženske studije.

5. Grubić, P. (2012). Izloženost kulturi. U: B. Skoko, P. Grubić (ur.), Kultura pušenja od tabua do tabua, Zagreb, 2012 (11-13). Zagreb: Novelti millenium.

6. Hrvatski biografski leksikon, (1983.-). Zagreb, 2. sv. 1989. Zagreb: Leksikografski zavod Miroslav Krleža.

7. Kolešnik, Lj. (1999). Feministička intervencija u suvremenu likovnu kulturu. U: Lj. Kolešnik (ur.), Feministička likovna kritika i teorija likovnih umjetnosti: izabrani tekstovi, Zagreb, 1999 (I-X), Zagreb: Centar za ženske studije.

8. Kolešnik, Lj. (2000). Autoportreti Naste Rojc: stvaranje predodžbe naglašenog rodnog identiteta u hrvatskoj umjetnosti ranog modernizma. Radovi Instituta za povijest umjetnosti, XXIV (24): 187-204.

9. Lah, N. (2012). Medijacijska funkcija umjetničke kritike između povijesti i suvremenosti. Ars Adriatica, II (2): 269-280.

10. Linkler, K. (1999). Prikazivanje spolnosti. U: Ljiljana Kolešnik (ur.), Feministička likovna kritika i teorija likovnih umjetnosti: izabrani tekstovi, Zagreb, 1999 (115-140). Zagreb: Centar za ženske studije.

11. Nochlin, L. (1999). Zašto nema velikih umjetnica? Feministička likovna kritika i teorija likovnih umjetnosti: izabrani tekstovi, Zagreb, 1999 (1-26). Zagreb: Centar za ženske studije.

12. Pejić, P. M. (2004). Slikar fra Josip Rossi. Radovi Zavoda za povijesne znanosti HAZU u Zadru, XLVI (46): 325-333.

13. Petričić, A. (1959). Zadarski slikari u XIX. stoljeću. Radovi Instituta JAZU u Zadru, VI (4-5): 215-238.

14. Petricioli, I. (2003). Franjo Salghetti -Drioli. Zadar: Narodni muzej; Zagreb: Institut za povijest umjetnosti.

15. Pollock, G. (1999). Modernost i prostori ženskosti. U: Lj. Kolešnik (ur.), Feministička likovna kritika i teorija likovnih umjetnosti: izabrani tekstovi, Zagreb, 1999 (157196). Zagreb: Centar za ženske studije.

16. Skoko, B. (2012). Kvaliteta dostojna cara: car Franjo Josip I. i uživanje u duhanu. U: B. Skoko i P. Grubić (ur.), Kultura pušenja - od tabua do tabua, Zagreb, 2012 (30-37). Zagreb: Novelti millenium.

17. Srhoj Čerina, Lj. (2008). Šezdeset godina Galerije umjetnina u Zadru. Zadar: Narodni muzej.

18. Stagličić, M. (2011). Urbanistički razvoj grada i likovne umjetnosti u Zadru: 1800.1914. U: Š. Batović (ur.), Zadar za austrijske uprave, (str. 259-396). Zadar: Matica hrvatska.

19. Travirka, A. (2011). Likovna kultura u Zadru za austrijske vlasti. U: Š. Batović (ur.), Zadar za austrijske uprave, (str. 397-788). Zadar: Matica hrvatska. 